Primljen / Received: 27.8.2016. Ispravljen / Corrected: 14.10.2016.

Prihvaćen / Accepted: 28.2.2017.

Dostupno online / Available online: 10.11.2017.

\section{Physico-mechanical properties of fly ash applicable in road construction}

Authors:

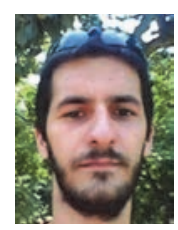

${ }^{1}$ Miloš Šešlija, MSc. CE slavijasrb@gmail.com

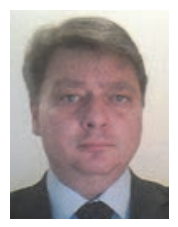

${ }^{1}$ Prof. Nebojša Radović, PhD. CE radovic.nebojsa62@gmail.com

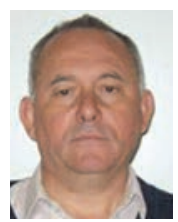

${ }^{1}$ Prof. Milinko Vasić, PhD. Geol. vaske@uns.ac.rs

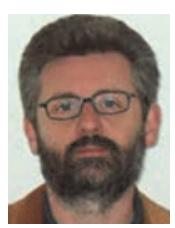

1Prof. Mitar Đogo, PhD. CE mitar@uns.ac.rs

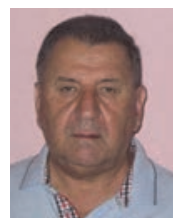

${ }^{2}$ Milovan Jotić, BSc. Geol. jotic@highway.rs

${ }^{1}$ University of Novi Sad, Faculty of Technical Sciences Department of Civil Engineering and Geodesy

${ }^{2}$ Highway Institute, Belgrade

\author{
Miloš Šešlija, Nebojša Radović, Milinko Vasić, Mitar Đogo, Milovan Jotić
}

Preliminary note

\section{Physico-mechanical properties of fly ash applicable in road construction}

An experimental research of physico-mechanical properties of fly ash and ash stabilized with lime and cement, as used in road construction, is presented in the paper. The binder was added in the proportion of 2,4 and $6 \%$ of the total quantity of fly ash. The testing revealed that ash samples with and without binder can be used for improvement of foundation soil and for construction of embankments and subgrade layers, but are not recommended for construction of subbase and base courses. The research is based on the use of fly ash for road construction, i.e. as a substitute for natural materials in construction industry, as this use would save natural resources whose reserves are limited.

\author{
Key words: \\ fly ash, physico-mechanical properties, cement, lime
}

Prethodno priopćenje

Miloš Šešlija, Nebojša Radović, Milinko Vasić, Mitar Đogo, Milovan Jotić

Fizikalno-mehanička svojstva letećeg pepela primjenjivog pri gradenju cesta

U radu je prikazano eksperimentalno istraživanje fizikalno-mehaničkih svojstava letećeg pepela i stabiliziranog pepela s dodatkom vapna i cementa primjenjivog za gradnju cesta. Vezivo je dodavano sa 2,4 i6 \% u odnosu na ukupnu količinu letećeg pepela. Nakon izvršenih ispitivanja uočljivo je da uzorci pepela bez dodataka i s dodatkom veziva mogu koristiti za izradu temeljnog tla, nasipa i posteljice, dok za izradu nosivih slojeva nisu preporučljivi. Istraživanje se temelji na korištenju letećeg pepela za izgradnju cesta, odnosno kao zamjena prirodnim materijalima u građevinarstvu, pri čemu se štede prirodni resursi čije su rezerve ograničene.

Ključne riječi:

leteći pepeo, fizikalno-mehanička svojstva, cement, vapno

Vorherige Mitteilung

Miloš Šešlija, Nebojša Radović, Milinko Vasić, Mitar Đogo, Milovan Jotić

Physikalisch-mechanische Eigenschaften von Flugasche, die beim Straßenbau eingesetzt wird

In der Arbeit wird eine experimentelle Untersuchung der physikalisch-mechanischen Eigenschaften von Flugasche und der stabilisierten Asche mit Zugabe von Kalk und Zement im Straßenbau dargestellt. Der Anteil des Bindemittels betrug 2,4 und 6\% der Gesamtmenge von Flugasche. Die Untersuchungen haben gezeigt, dass sich die Ascheproben ohne und mit Zusatz von Bindemittel für die Herstellung des Baugrunds, der Dammschüttung und des Planums eignen, während sie für die Herstellung von tragenden Schichten nicht zu empfehlen sind. Die Untersuchung beruht auf der Verwendung von Flugasche im Straßenbau, bzw. als Ersatz für natürliche Rohstoffe im Bauwesen. Dabei wird eine schonende Verwendung der natürlichen Ressourcen ermöglicht, deren Bestände ohnehin begrenzt sind.

Schlüsselwörter:

Flugasche, physikalisch-mechanische Eigenschaften, Zement, Kalk 


\section{Introduction}

Fly ash is a mineral by-product formed by combustion of finely crushed coal in the air flow. It is made of fine particles, mainly of silica glass, and these particles are formed using electrostatic separator from gaseous combustion products. Because they are produced and hardened in flue gases, particles of fly ash are characterized by small volume, they are spherical in shape, and measure 0.074 to $0.005 \mathrm{~mm}$ in diameter. They are easily movable and can therefore cause a number of problems to the environment. Ash landfills are highly detrimental to the environment, which is reflected in the pollution of air, soil, surface water and groundwater, vegetation cover, as well as in the disruption of the ecosystem, which affects human health. All these negative environmental effects caused by fly ash can be eliminated or reduced if fly ash is used as building material for the construction of roads and other pavement surfaces [1]. In Europe, fly ash is most commonly used for the production of cement and concrete, for the construction of embankments, for soil replacement, etc. [2]. The widest use of fly ash is in the production of cement because it exhibits pozzolanic properties [3, 4].

Most international and domestic research is based on the use of fly ash as a substitute for cement in concrete production [5-8]. Mohanty and Patra [9] conducted dynamic testing for construction of embankments made of fly ash. Some authors established that the addition of fly ash ensures greater strength, moisture, resistance to cyclic freezing and thawing, fatigue, density and tensile strength of asphalt [10-12]. Suheibani [13] investigated the use of fly ash as asphalt additive and discovered that the addition of this filler enables longer service life, while also improving abrasion resistance and tensile strength. Based on the index of workability at various temperatures, Cabrera Zoorob [14] concluded that fly ash can be mixed and compacted at low temperatures, such as $110^{\circ} \mathrm{C}$ and $85^{\circ} \mathrm{C}$, without any adverse effects. Baykal et al. [15] studied the use of fly ash for embankment construction in cold regions. After testing, the authors came to conclusion that fly ash can in effect be used for construction of embankments in cold regions. Some authors $[16,17]$ used fly ash for soil stabilization. Based on presented research, it was concluded that fly ash improves important properties of soil. Tadic et al. [18] analysed the use of fly ash in road construction. After testing, the authors came to conclusion that both mixtures can be used for improvement of foundation soil, and for construction of embankment and subgrade for pavement structures. The paper [19] analysed fly ash and slag with and without lime binder, and with and without 0-63 mm aggregate fractions. After testing, the authors concluded that fly ash and slag can be used in combination with lime and stone aggregate in various road and embankment layers, i.e. for improvement of foundation soil, construction of embankment and subgrade for pavement structures, and construction of lower base courses in road construction.

The subject of this paper is laboratory testing of physical and mechanical properties of fly ash generated at the thermal power plants Nikola Tesla (PPNT A) and Nikola Tesla B (PPNT B).
Physico-mechanical properties (uniaxial compressive strength, indirect tensile strength, elastic modulus, resistance to water index, and resistance to the influence of frost index) reveal that it can be used as a construction material, thus contributing to reduction in the use of natural resources for road construction. This paper is aimed at examining physical and mechanical properties of fly ash with and without binder (cement and lime), and at establishing a correlation between the physicomechanical properties.

\section{Preparation and testing of samples}

Fly ash samples were taken at PPNT A and PPNT B (Figure 1). Thermal power plants NT A and NT B use coal from the Kolubara basin. The Kolubara coal basin is known as one of the largest and most important lignite basins in Serbia. This large basin abounds in Neogene and Quaternary sediments, which lie transgressively and discordantly across the Palaeozoic and Mesozoic substrate, locally penetrating dacite-andesite and pyroclastic rocks in eastern part. Previous quality investigations were made through numerous analyses of charcoal from boreholes and the coal floor. The corresponding results are presented in Table 1 [20].

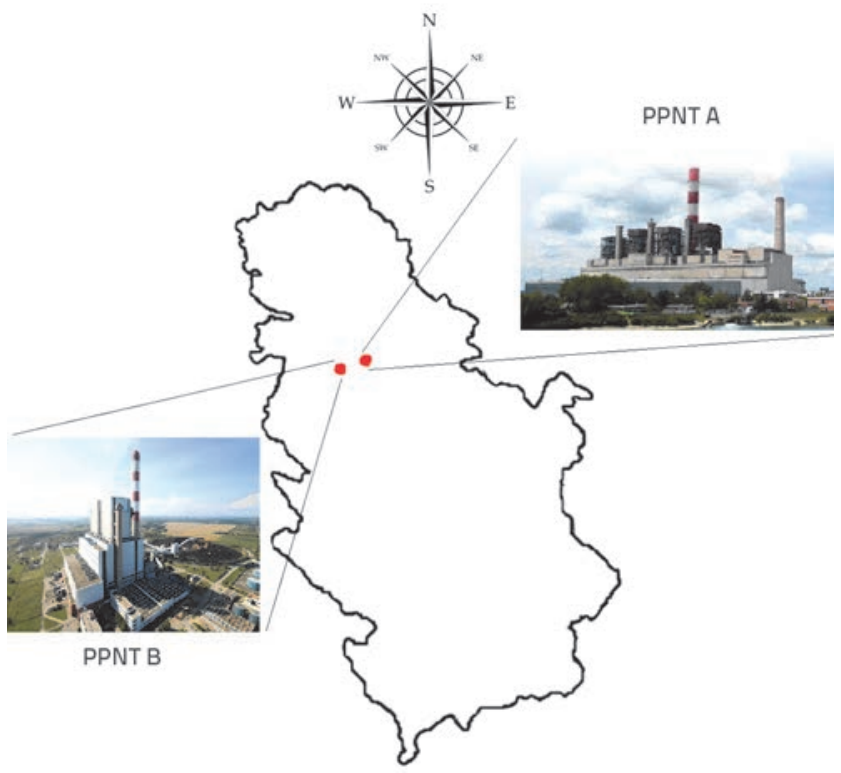

Figure 1. Location of test sites

Based on these results, it can be seen that the quality of coal in the deposit increases with depth - from roof to foot carbon layer. Therefore, the Kolubara coal basin has very significant lignite reserves that form the basis for further planning and organization of coal production and investigation of reservoirs [20].

The ash is sampled directly in the vicinity of electrostatic precipitators in the cooling phase, before the ash comes into contact with water. The necessary quantity of samples for laboratory testing of ash was provided on three occasions. The samples were prepared with and without the addition of binders. Cement and lime are used as binder. Basic properties of cement, lime and fly 
Table 1. Quality of coal at Kolubara basin

\begin{tabular}{|c|c|c|c|}
\hline Elements of testing & Roof seam layer I [\%] & Main layer II [\%] & Foot layer III [\%] \\
\hline Humidity & 57.10 & 46.00 & 19.15 \\
\hline Ash & 15.04 & 15.33 & 0.91 \\
\hline Total sulphur & 0.39 & 0.42 & 0.20 \\
\hline Ash sulphur & 0.15 & 0.20 & 0.71 \\
\hline Combustive sulphur & 0.24 & 0.22 & 17.23 \\
\hline C-fix & 10.21 & 15.34 & 21.20 \\
\hline Evaporative & 17.65 & 22.83 & 38.43 \\
\hline Combustive & 27.86 & 38.67 & 10.22 \\
\hline Upper calorific value [kJ/kg] & 6.95 & 10.16 & 8.82 \\
\hline Lower calorific value [kJ/kg] & 5.27 & 8.61 & 19.72 \\
\hline Carbon & 15.10 & 25.62 & 1.93 \\
\hline Hydrogen & 1.92 & 2.39 & 0.40 \\
\hline Combustive sulphur & 0.21 & 0.22 & 9.07 \\
\hline Nitrogen + oxygen & 7.25 & 10.44 & \\
\hline
\end{tabular}

Table 2. Properties of cement, lime and fly ash

\begin{tabular}{|c|c|c|c|c|}
\hline \multirow{3}{*}{ Properties } & \multicolumn{4}{|c|}{ Integral component } \\
\hline & \multirow{2}{*}{ CEM II/B-M (V-L) 32.5 R } & \multirow{2}{*}{ Hydrated lime } & \multicolumn{2}{|c|}{ Fly ash } \\
\hline & & & PPNT A & PPNT B \\
\hline Loss on ignition [\%] & 8.42 & 25.25 & 9.88 & 10.50 \\
\hline $\mathrm{SO}_{3}[\%]$ & 2.72 & 0.31 & 0.12 & 0.16 \\
\hline $\mathrm{SiO}_{2}[\%]$ & 18.25 & 0.08 & 51.06 & 52.12 \\
\hline $\mathrm{Fe}_{2} \mathrm{O}_{3}[\%]$ & 2.25 & 0.02 & 6.14 & 6.30 \\
\hline $\mathrm{Al}_{2} \mathrm{O}_{3}[\%]$ & 5.46 & 0.05 & 20.50 & 20.97 \\
\hline $\mathrm{CaO}[\%]$ & 60.37 & 71.38 & 7.27 & 5.51 \\
\hline $\mathrm{MgO}[\%]$ & 1.95 & 2.67 & 2.70 & 2.30 \\
\hline $\mathrm{Cl}[\%]$ & 0.006 & - & 0.006 & 0.003 \\
\hline Density $\left[\mathrm{g} / \mathrm{cm}^{3}\right]$ & 3.02 & 2.26 & 2.10 & 2.12 \\
\hline
\end{tabular}

ash from PPNT A and PPNT B are shown in Table 2. The proportion of binder in the mixture was 2,4 and $6 \%$ of the total mass of fly ash. The classification of fly ash according to EN 14227-4 [21], for both power plants, reveals that the fly ash belongs to the class of calcareous ashes. This classification is based on the proportion of calcium oxide $(\mathrm{CaO})$ and, according to classification ASTM C-618 [22], fly ash for both thermal power plants belongs to the class $F$, the so-called acidic ashes. The ASTM C-618 classification is based on the content of certain oxides (silicon dioxide $\left(\mathrm{SiO}_{2}\right)$, aluminium oxide $\left(\mathrm{Al}_{2} \mathrm{O}_{3}\right)$, and iron trioxide $\left(\mathrm{Fe}_{2} \mathrm{O}_{3}\right)$, and further includes calcium oxide (CaO), which significantly affects pozzolanic properties of fly ash. The Class F, the so-called acidic ashes, has a low CaO content (less than $10 \%$ ) and at least $70 \%$ of oxides, while the fly ash Class C has a high $\mathrm{CaO}$ content (over $10 \%$ ), but at least $50 \%$ of oxides. Although exhibiting pozzolanic properties, vitreous silica dioxide and aluminium oxide in class $\mathrm{F}$ ashes require a means for improving their bonding characteristics, such as Portland cement or lime in the presence of water, in order to start reaction and form calcium silicate hydrate.

The particle size distribution of fly ash is presented in Table 3. It is defined as the mean value of three examined samples for both thermal power plants. The composition of mixtures is shown in Table 4. After the samples were formed, the required amounts of materials were determined for the following physico-mechanical tests:

- Uniaxial compressive strength;

- Indirect tensile strength;

- Modulus of elasticity;

- Index of resistance to the influence of water;

- Index of resistance to the influence of frost.

Parameters obtained by determining the uniaxial compressive strength and free lateral expansion were used to gain a general insight into characteristics of the fly ash as construction material 
Table 3. Particle size distribution of fly ash

\begin{tabular}{|c|c|c|c|c|c|c|c|c|}
\hline Sieve $[\mathrm{mm}]$ & 4.0 & 2.0 & 1.0 & 0.5 & 0.25 & 0.125 & 0.09 & 0.063 \\
\hline PPNT A, pass [\%] & 100 & 100 & 99 & 97 & 91 & 73 & 60 & 57 \\
\hline PPNT B, pass [\%] & 100 & 100 & 100 & 98 & 94 & 76 & 62 & 58 \\
\hline
\end{tabular}

Table 4. Composition of fly ash mixtures

\begin{tabular}{|c|c|c|c|c|c|}
\hline Location & Composition & $\begin{array}{l}\text { Fly ash } \\
{\left[\mathrm{kg} / \mathrm{m}^{3}\right]}\end{array}$ & $\begin{array}{c}\text { CEM II/B-M (S-L) } 32.5 \\
\text { R }\left[\mathrm{kg} / \mathrm{m}^{3}\right]\end{array}$ & $\begin{array}{c}\text { Hydrated lime } \\
{\left[\mathrm{kg} / \mathrm{m}^{3}\right]}\end{array}$ & $\begin{array}{c}\text { Water } \\
{\left[\mathrm{kg} / \mathrm{m}^{3}\right]}\end{array}$ \\
\hline \multirow{7}{*}{ PPNT A } & FA & 1023.9 & - & - & 512.4 \\
\hline & $F A-2 V$ & 1008.7 & - & 20.2 & 500.3 \\
\hline & $F A-4 V$ & 997.5 & - & 39.9 & 486.4 \\
\hline & FA-6V & 989.3 & - & 59.4 & 470.9 \\
\hline & FA-2C & 1009.1 & 20.2 & - & 500.5 \\
\hline & $F A-4 C$ & 995.5 & 39.8 & - & 485.4 \\
\hline & FA-6C & 982.3 & 58.9 & - & 467.6 \\
\hline \multirow{7}{*}{ PPNT B } & FA & 1130.7 & - & - & 466.6 \\
\hline & $F A-2 V$ & 1119.9 & - & 22.4 & 452.4 \\
\hline & FA-4V & 1105.1 & - & 44.2 & 440.0 \\
\hline & FA-6V & 1090.6 & - & 65.4 & 427.5 \\
\hline & FA-2C & 1129.6 & 22.6 & - & 450.4 \\
\hline & FA-4C & 1133.2 & 45.3 & - & 431.9 \\
\hline & FA-6C & 1136.3 & 68.2 & - & 413.6 \\
\hline
\end{tabular}

and to enable calculation of stability and bearing capacity. A cylindrical sample $100 \mathrm{~mm}$ in diameter and $200 \mathrm{~mm}$ in height, which fulfils the required height to diameter ratio of 2:1 [23], was used in this experiment. Samples were prepared in a special threepart mould and compacted according to the Proctor procedure in five layers. The samples were cured in two basic ways, after 7 and 28 days, in a wet chamber. The modulus of elasticity is the stress to strain ratio. The relationship between stress defined at $30 \%$ of maximum uniaxial compressive strength and the corresponding relative deformation in the first cycle of the load, was established through examinations. The modulus of elasticity was tested according to EN 13286-43 [24].

Also, materials were tested with regard to the impact of water and frost. The impact of water was analysed on submerged samples after 28 days of cure in a wet chamber, and one-day submersion in water up to $3 / 4$ of sample height. By comparing the uniaxial compressive strength of samples prepared in this way with the corresponding samples without submersion, the index of resistance to water (Rp) was defined, with the index value expressed as percentage. The use of ash in lower base courses of road pavements is susceptible to the influence of frost which, according to technical regulations, penetrates to a depth of $0.8 \mathrm{~m}$ [25] depending on weather conditions. All frostrelated tests were carried out on samples that were previously cured in a wet chamber for 10 days and then exposed to frost in
14 cycles. For the remaining time, until 28 days, samples were kept in a wet chamber, all in accordance with SRPS U.B1.50 [26]. Most granular materials can not be directly exposed to tension forces. The indirect tensile strength method was developed for this purpose. The indirect tensile strength (Brazilian test) is mainly used for stabilized bearing layers. Cylindrical samples $102 \mathrm{~mm}$ in diameter and $116 \mathrm{~mm}$ in length, specially prepared in a standard mould according to Proctor procedure in three layers [27], were used in this experiment. These samples were cured in a wet chamber for 28 days.

\section{Results and discussion}

The results of physico-mechanical properties after 7 and 28 days are shown in Table 5. Frost and water resistance indices are presented in Figure 5. Mean values are given for all tested samples. Three samples were tested for each power plant, i.e. 6 tests of fly ash in total.

The uniaxial compressive strength of the control mixture from PPNT A, i.e. the sample made from fly ash without binder, amounted to $0.41 \mathrm{MPa}$ and $0.53 \mathrm{MPa}$ at the age of 7 and 28 days, respectively. The fly ash control mixture from PPNT $B$, cured in wet chamber, exhibited the uniaxial compressive strength of only 0,33 MPa or 0,64 MPa at the age of 28 days. Reduction of the control mixture PPNT A amounts to about 17.2 
Table 5. Properties of fly ash with and without binder

\begin{tabular}{|c|c|c|c|c|c|c|c|c|c|c|c|}
\hline \multirow[t]{2}{*}{ Location } & \multirow[t]{2}{*}{ Mixes } & \multirow[t]{2}{*}{ Age of sample } & \multicolumn{3}{|c|}{$\begin{array}{l}\text { Uniaxial compressive strength } \\
{[\mathrm{MPa}]}\end{array}$} & \multicolumn{3}{|c|}{$\begin{array}{c}\text { Indirect tensile strength } \\
{[\mathrm{MPa}]}\end{array}$} & \multicolumn{3}{|c|}{$\begin{array}{c}\text { Modulus of elasticity } \\
{[\mathrm{GPa}]}\end{array}$} \\
\hline & & & MVal & StDev & cov & MVal & StDev & cov & MVal & StDev & cov \\
\hline \multirow{14}{*}{ PPNT A } & \multirow{2}{*}{ FA } & 7 & 0.41 & 0.011 & 2.72 & & & & 0.07 & 0.010 & 14.45 \\
\hline & & 28 & 0.53 & 0.008 & 1.52 & 0.04 & 0.004 & 10.07 & 0.16 & 0.006 & 4.07 \\
\hline & \multirow{2}{*}{ FA-2V } & 7 & 0.79 & 0.003 & 0.40 & & & & 0.16 & 0.025 & 15.52 \\
\hline & & 28 & 1.09 & 0.044 & 4.07 & 0.08 & 0.047 & 58.26 & 0.23 & 0.025 & 10.89 \\
\hline & \multirow{2}{*}{ FA-4V } & 7 & 0.81 & 0.045 & 5.61 & & & & 0.18 & 0.012 & 6.62 \\
\hline & & 28 & 1.80 & 0.069 & 3.83 & 0.29 & 0.031 & 10.77 & 0.31 & 0.041 & 13.08 \\
\hline & \multirow{2}{*}{ FA-6V } & 7 & 0.84 & 0.088 & 10.45 & & & & 0.16 & 0.030 & 18.63 \\
\hline & & 28 & 2.36 & 0.036 & 1.54 & 0.35 & 0.068 & 19.11 & 0.43 & 0.028 & 6.69 \\
\hline & \multirow{2}{*}{ FA-2C } & 7 & 1.15 & 0.008 & 0.69 & & & & 0.22 & 0.007 & 3.15 \\
\hline & & 28 & 1.31 & 0.081 & 6.15 & 0.08 & 0.002 & 2.25 & 0.26 & 0.049 & 18.63 \\
\hline & \multirow{2}{*}{ FA-4C } & 7 & 1.32 & 0.010 & 0.78 & & & & 0.29 & 0.003 & 1.00 \\
\hline & & 28 & 1.64 & 0.029 & 1.75 & 0.11 & 0.003 & 3.20 & 0.29 & 0.002 & 0.70 \\
\hline & \multirow{2}{*}{ FA-6C } & 7 & 1.23 & 0.019 & 1.59 & & & & 0.27 & 0.011 & 4.02 \\
\hline & & 28 & 1.68 & 0.023 & 1.37 & 0.19 & 0.024 & 13.08 & 0.33 & 0.014 & 4.35 \\
\hline \multirow{14}{*}{ PPNT B } & \multirow{2}{*}{ FA } & 7 & 0.33 & 0.026 & 7.77 & & & & 0.12 & 0.006 & 5.05 \\
\hline & & 28 & 0.64 & 0.035 & 5.57 & 0.06 & 0.013 & 20.04 & 0.16 & 0.011 & 6.69 \\
\hline & \multirow{2}{*}{ FA-2V } & 7 & 0.61 & 0.018 & 2.90 & & & & 0.18 & 0.008 & 4.37 \\
\hline & & 28 & 1.29 & 0.050 & 3.88 & 0.13 & 0.016 & 12.63 & 0.19 & 0.029 & 14.97 \\
\hline & \multirow{2}{*}{ FA-4V } & 7 & 0.81 & 0.024 & 3.00 & & & & 0.19 & 0.006 & 3.37 \\
\hline & & 28 & 2.00 & 0.246 & 12.34 & 0.32 & 0.012 & 3.76 & 0.33 & 0.056 & 17.19 \\
\hline & \multirow{2}{*}{ FA-6V } & 7 & 1.09 & 0.085 & 7.81 & & & & 0.24 & 0.007 & 2.78 \\
\hline & & 28 & 3.37 & 0.071 & 2.12 & 0.37 & 0.022 & 5.78 & 0.29 & 0.009 & 3.06 \\
\hline & \multirow{2}{*}{ FA-2C } & 7 & 0.62 & 0.070 & 11.26 & & & & 0.20 & 0.007 & 3.77 \\
\hline & & 28 & 0.80 & 0.013 & 1.62 & 0.09 & 0.003 & 3.45 & 0.23 & 0.007 & 3.31 \\
\hline & \multirow{2}{*}{ FA-4C } & 7 & 0.99 & 0.118 & 11.92 & & & & 0.26 & 0.005 & 1.74 \\
\hline & & 28 & 1.59 & 0.069 & 4.32 & 0.13 & 0.027 & 20.68 & 0.42 & 0.021 & 5.09 \\
\hline & \multirow{2}{*}{ FA-6C } & 7 & 1.47 & 0.037 & 2.51 & & & & 0.32 & 0.026 & 8.26 \\
\hline & & 28 & 2.15 & 0.120 & 5.58 & 0.19 & 0.007 & 3.71 & 0.41 & 0.017 & 4.17 \\
\hline
\end{tabular}

PPNT A: thermal power plant Nikola Tesla A, PPNT B: thermal power plant Nikola Tesla B, FA: fly ash without binder,

FA - 2L: fly ash with $2 \%$ of lime, FA - 2C: fly ash with $2 \%$ of cement, MVal: Mean values, StDev: standard deviation, COV: coefficient of variation [\%]

$\%$ compared to the uniaxial compressive strength of the control mixture for PPNT $B$ at the age of 28 days. It is obvious that the change of chemical composition of fly ash has a considerable effect on the change of test results for fly ash [15-19].

It can clearly be seen in Figure 2 (left) that the early uniaxial compressive strength of fly ash with binder (cement and lime) is higher at the age of 7 days compared to compressive strength of the control sample of fly ash. However, a significant increase of the uniaxial compressive strength was observed at the age of 28 days. The uniaxial compressive strength of samples increased with the quantity of binder (cement and lime). Samples containing lime as binder had substantially better properties compared to samples with cement, but only when more than $4 \%$ of binder was added to the mixture. The increase for the sample FA- $6 \mathrm{~L}$ is about $40.47 \%$ compared to FA$6 \mathrm{C}$ sample at the age of 28 days. The results are similar to those published by Tadic at al., and Imamovic et al. [18, 19].

Figure 2 (right) shows samples of fly ash from PPNT B at the age of 7 and 28 days. The test results are similar to uniaxial compressive strength results for samples from PPNT $A$. 

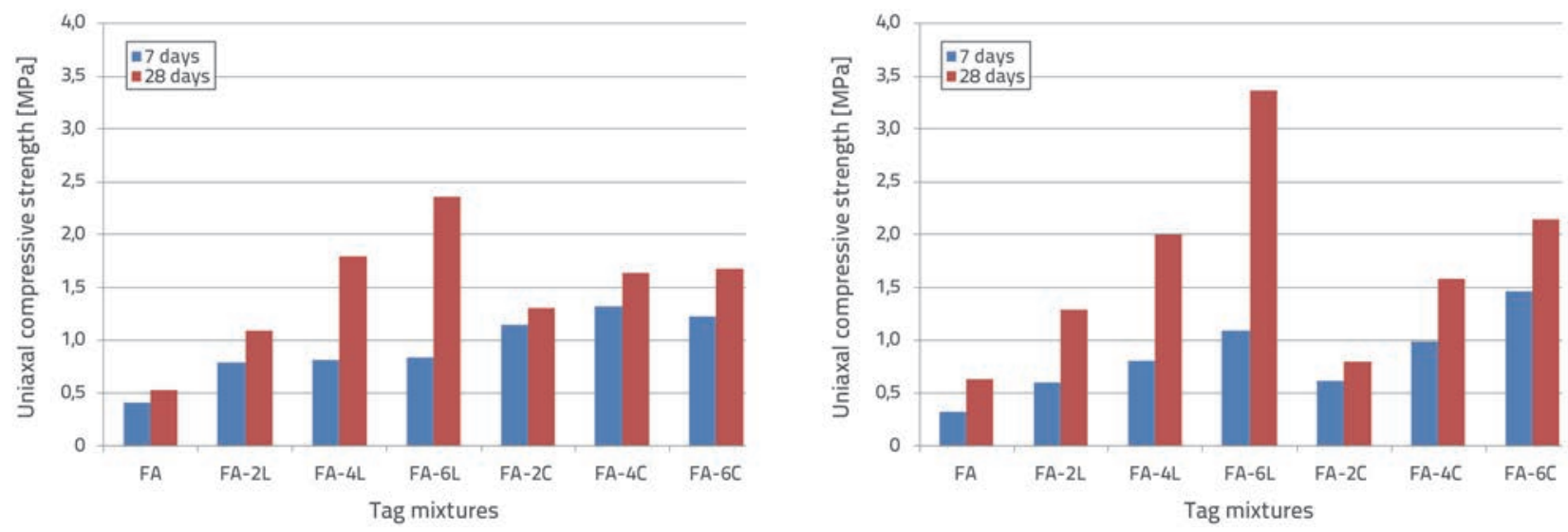

Figure 2. Uniaxial compressive strength of fly ash from PPNT A (left) and PPNT B (right)

However, the uniaxial compressive strength for samples containing lime as binder is significantly higher at the age of 28 days than the uniaxial compressive strength registered at PPNT A. The uniaxial compressive strength increases by adding larger quantities of lime. Unlike PPNT A samples with lime, the uniaxial compressive strength of PPNT B samples containing 2, 4 and $6 \%$ of lime exceeds that of the control samples by 2,3 , and 5 times, respectively. The addition of cement and lime with natural materials (sand and gravel) makes the binder behave like a basic hydraulic binder, while the same binder when added to the fly ash behaves as activator of pozzolanic properties, which results in a different course of hydration. The course of hydration directly affects the value and speed of reaching the final strength, as can be seen in Figure 2 where fly ash with cement behaves differently compared to fly ash with lime. The degree of hydration of the samples was monitored through an increase in the uniaxial compressive strength and phase changes of mineral composition via theX-ray diffractometer analysis of previously broken samples. These observations suggest that activation of the tested ashes, with such a small amount of additives, just started in the period to 28 days and that the process would continue over a longer period of time, which would provide better and clearer results concerning mineral composition. The only mineral in the analysed samples is calcite in crystalline form, which has been identified as the product of reaction in the ash - binder - water system, although its quantity is relatively small and varies depending on a number of factors. Some of the factors are the nature of the ash, sort of additives (lime or cement), participation of additives, and time of cure. It was noted that the participation of calcite mainly increased with a higher participation of additives. The samples with no additive do not contain calcite, or it is present in traces. Also, the samples with cement generally have a smaller amount of calcite compared to the corresponding mixtures with lime.

According to SRPS U.E9.024 [28], the samples with cement stabilization cannot be used for upper and lower base courses of load-bearing pavement structures. All samples do not comply with certain minimum values according to standard [28], as shown in Table 6.

Samples made with lime stabilization, tested after 7 days, can be used for foundation soil, construction of embankments, and in subgrade construction, while only sample FA-6L from PPNT B meets the requirement of SRPS U.E9.026 [29] for the substrate layer. The samples with lime stabilization, tested after 28 days, can be used for all road layers, except the samples from the two power plants with the addition of $2 \%$ of lime, because they do not comply with minimum values for load-bearing courses (Table 6).

Table 6. Characteristics of fly ash with and without binder

\begin{tabular}{|c|c|c|c|c|}
\hline \multirow[t]{2}{*}{ Layer } & \multicolumn{2}{|c|}{$\begin{array}{l}\text { Uniaxial compressive strength of } \\
\text { samples (stabilized with cement) } \\
\text { [MPa] [28] }\end{array}$} & \multicolumn{2}{|c|}{$\begin{array}{c}\text { Uniaxial compressive strength of } \\
\text { samples (stabilized with lime) } \\
\text { [MPa] [29] }\end{array}$} \\
\hline & After 7 days & After 28 days & After 7 days & After 28 days \\
\hline Foundation soil & - & - & 0.2 & 0.3 \\
\hline Construction of embankments & - & - & 0.3 & 0.4 \\
\hline Sub-base course & - & - & 0.4 & 0.5 \\
\hline Base course & - & - & 1.0 & 1.4 \\
\hline $\begin{array}{l}\text { The subgrade layers of pavement structures and } \\
\text { reinforcing layers and the lower bearing course of } \\
\text { highways. I and II class roads }\end{array}$ & $2-5.5$ & $3-6.5$ & - & - \\
\hline Lower bearing course of III and IV class roads & $1.5-4.5$ & $2.5-6$ & - & - \\
\hline
\end{tabular}



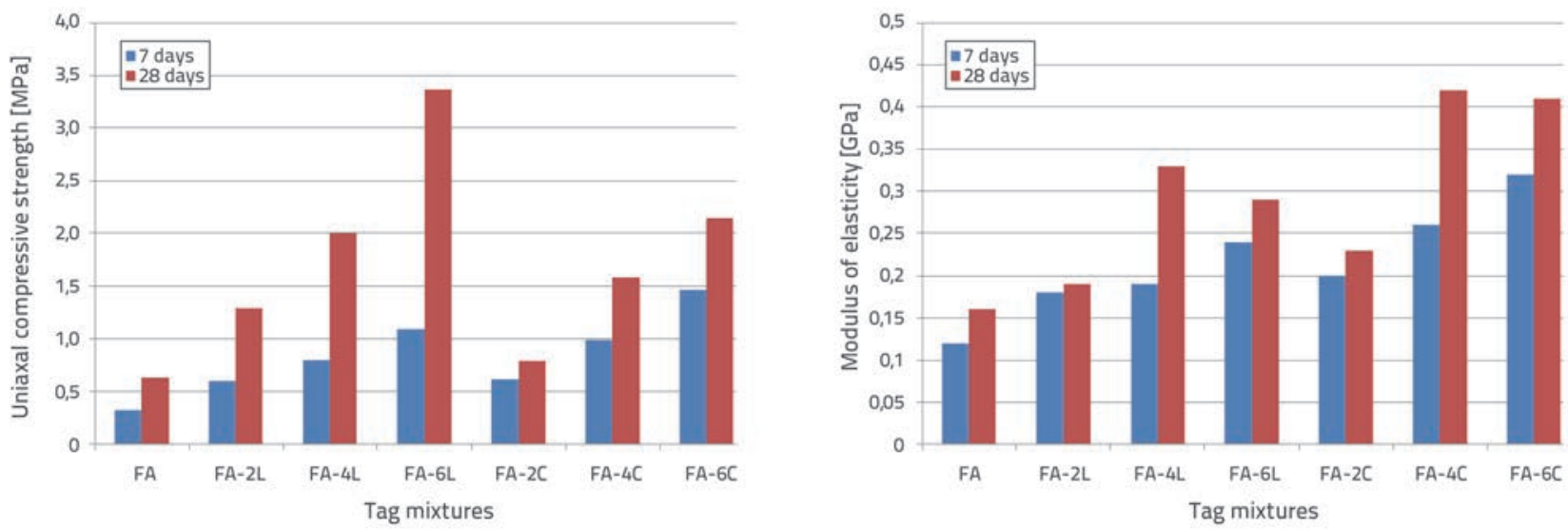

Figure 3. Modulus of elasticity for fly ash from PPNT A (left) and PPNT B (right)

The value of the modulus of elasticity at 7 and 28 days (Figure 3 ) and the indirect tensile strength at 28 days (Figure 4 ) were determined. It can be noted that the trends of elastic modulus and indirect tensile strength of the fly ash mixture with and without binder (cement and lime) are similar to the trends obtained for compressive strength.

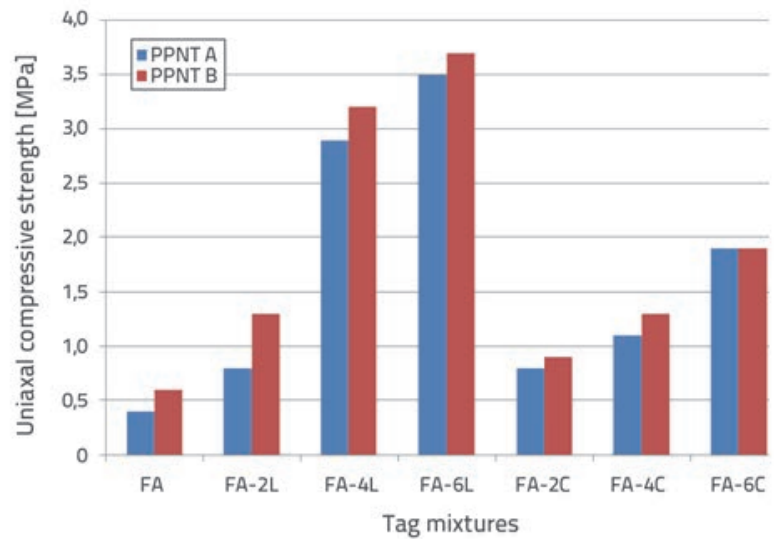

Figure 4. Indirect tensile strength for fly ash from PPNT A and PPNT B after $\mathbf{2 8}$ days

The maximum modulus of elasticity after 7 days was achieved at PPNT A with $4 \%$ of cement and at PPNT B with $6 \%$ of cement.
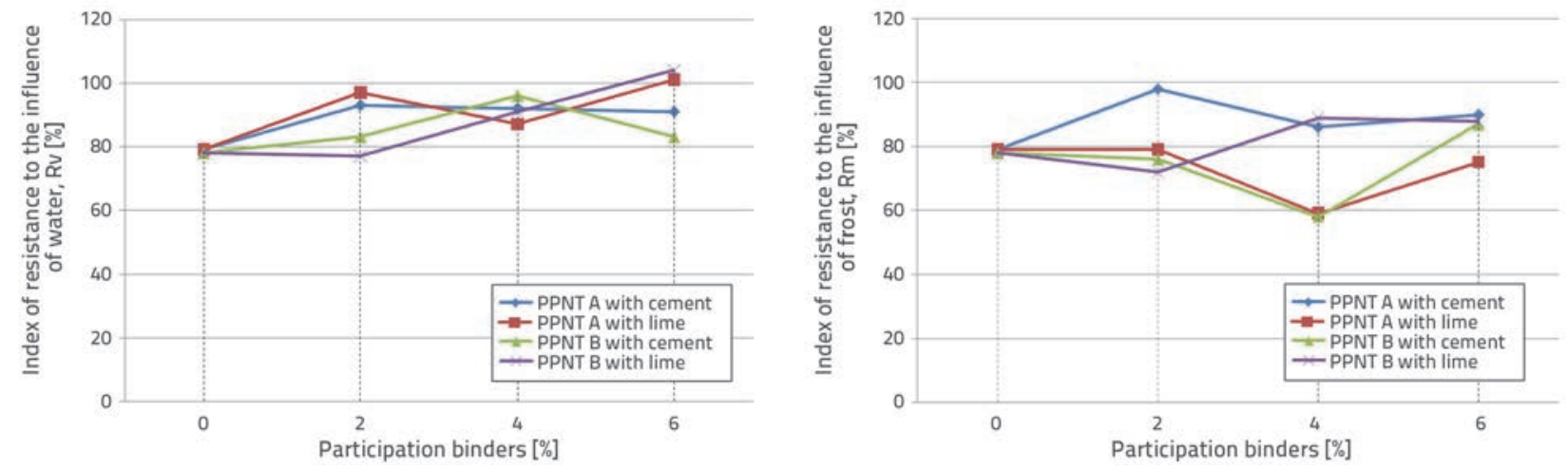

After 28 days, the maximum value of the modulus of elasticity was achieved at PPNT A with $6 \%$ of lime, while at PPNT B it was achieved with $4 \%$ of cement.

The indirect tensile strength was tested after 28 days only, and the maximum value was obtained with $6 \%$ of lime for both power plants. Baykla et al. [15] analysed the ashes without binder, where the indirect tensile strength was obtained as an approximate maximum examined value.

Results obtained by testing the index of resistance to the influence of water (Rp) are shown in Figure 5, where a considerable dispersion of results can be observed. It can also be observed that only a PPNT B sample with $2 \%$ of lime has a decrease in strength below $20 \%$, while other samples have no decrease in strength of more than $20 \%$. It can therefore be concluded that the tested samples are resistant to water impact. Sample values increase with an increase in the quantity of lime for both thermal power plants, while sample values decrease with an increase in the quantity of cement. The results of the index of resistance to the influence of frost are shown in Figure 5 (right). Factors that may affect the deformation of soil and pavement due to frost action are: grain size distribution, groundwater level, duration of frost, and temperature. Stabilized ash shows the expected higher sensitivity to the impact of frost, which is not the case for the impact of water. Figure 5 (right) shows that about $40 \%$ of all samples exhibit a small drop

Figure 5. Index of resistance to influence of water (left) and frost (right) 

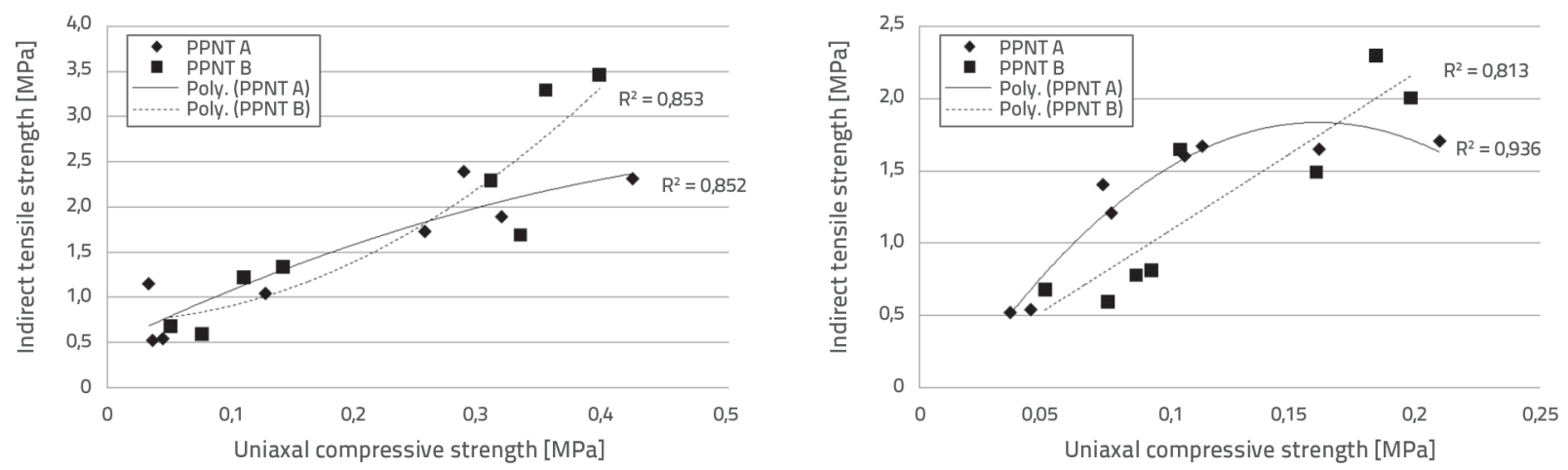

Figure 6. Relation between the uniaxial compressive strength and indirect tensile strength with lime (left) and cement (right) after 28 days
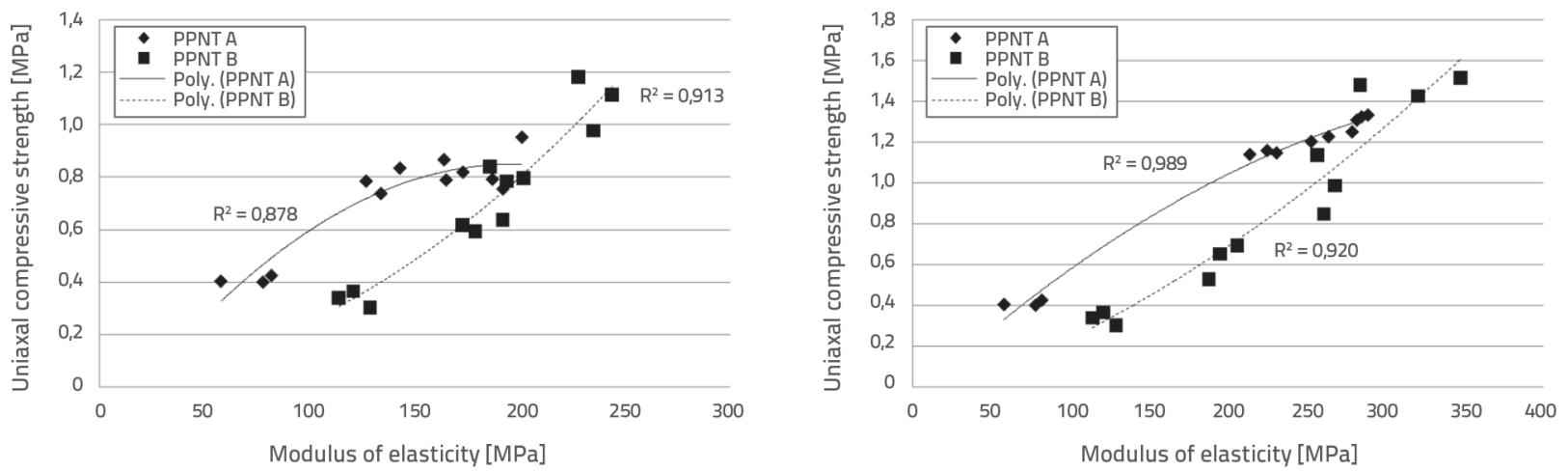

Figure 7. Relation between uniaxial compressive strength and modulus of elasticity with lime (left) and cement (right) after 7 days
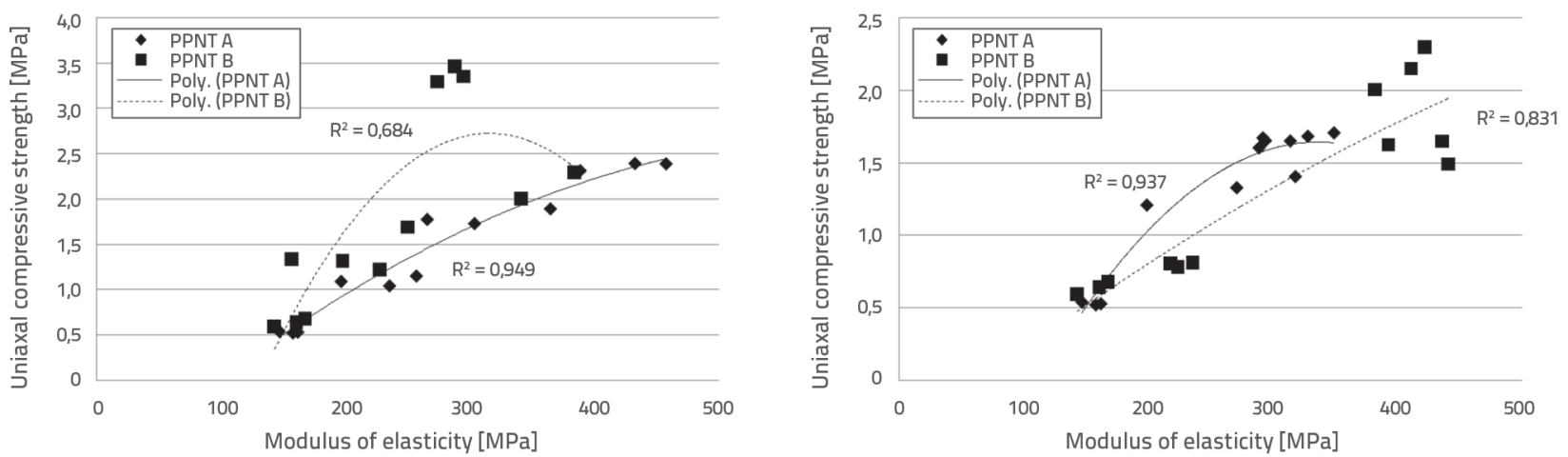

Figure 8. Relation between uniaxial compressive strength and modulus of elasticity with lime (left) and cement (right) after 28 days

in strength i.e. the decline does not exceed $20 \%$ of the initial value. Fly ash samples with or without binder (cement or lime), exhibiting a decline in strength of up to $20 \%$, are resistant to the influence of frost $[26,29]$. The tests carried out and presented in the paper $[18,19]$ show that all tested samples are resistant to frost, and that the decline in strength is in no case higher than $20 \%$.

\subsection{Relationship between physico-mechanical properties}

The relations between the physical and mechanical properties are presented in the initial part of the paper, which is followed by determination of correlation coefficients and their comparison between the two power plants. Relations were determined for all the samples using a polynomial function because this function provides the best correlation results. A total of 16 correlations were established ( 8 for PPNT A, and 8 for PPNT B). The relation between the uniaxial compressive strength and indirect tensile strength after 28 days is shown in Figure 6 . The relationships show good reliability between uniaxial compressive strength and indirect tensile strength results. Test results show that the strength increases with an increase in the quantity of binder for both power plants, where the samples with lime exhibit higher uniaxial compressive strength and indirect tensile strength values.

The relations between the uniaxial compressive strength and modulus of elasticity after 7 and 28 days are shown in Figures 

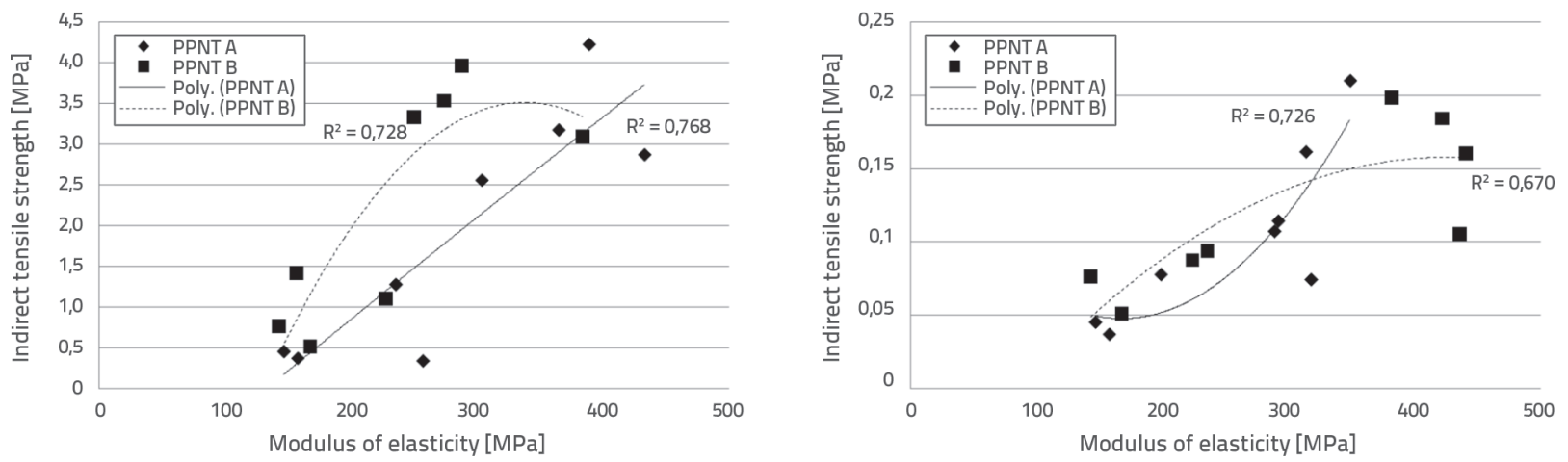

Figure 9. Relation between indirect tensile strength and modulus of elasticity with lime (left) and cement (right) after 28 days

7 and 8. These figures show that cement exhibits better properties after 7 days, while lime has better properties as a binder after 28 days. The ratio shows good reliability between uniaxial compressive strength and modulus of elasticity results.
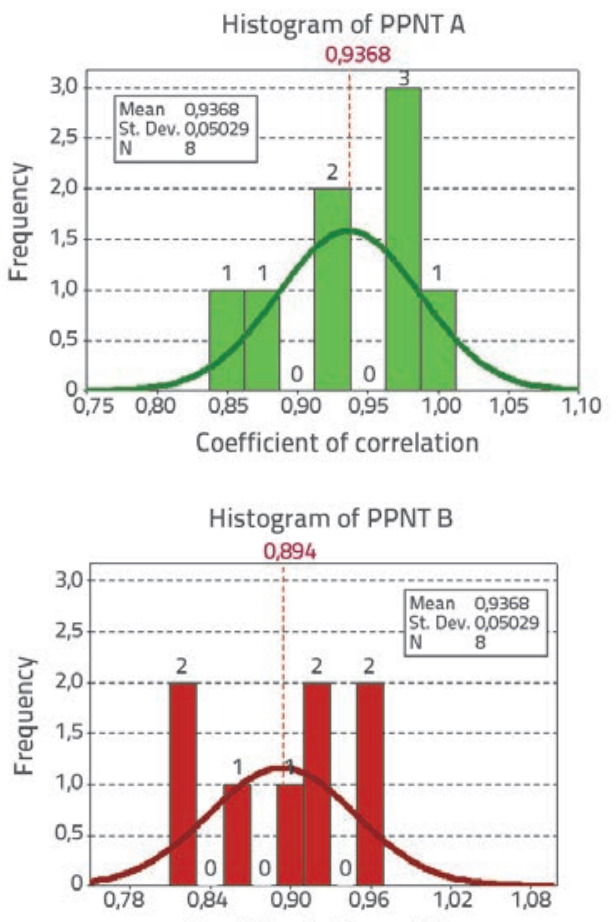

Coefficient of correlation

Figure 10. Histogram of fly ash from PPNT A and PPNT B (Mean Mean value; StDev - Standard deviation; N-Number of samples)

The relation between the indirect tensile strength and modulus of elasticity (Figure 9) has a good reliability for both power plants when using lime as binder, while for the cement and PPNT B, the obtained ratio was significantly different compared to other correlation coefficients. Figures 8 and 9 show that the uniaxial compressive strength and indirect tensile strength values decrease with an increase in the modulus of elasticity at PPNT B. The results are compared and shown in the histogram (Figure
10). The histogram shows frequency of the correlation coefficients, mean value of analysed results, standard deviation, and number of samples.

The histogram shows approximately the same frequency of all correlation coefficients for PPNT B, while for PPNT A high frequency occurs for the correlation coefficient 0.97, which points to a very strong correlation of samples. After analysis of relations and presentation of correlation-coefficient results, it can be concluded that the fly ash taken from PPNT A exhibits much better values between achieved dependences of physicomechanical properties, as compared to the fly ash taken from PPNT B.

\section{Conclusion}

The following conclusions can be made based on the research presented in this paper:

- Physico-mechanical properties of fly ash and stabilized ash with cement and lime from PPNT A and PPNT B are found in a wide range, in about $50 \%$, confirming that this material is suitable for the construction of foundation soil, embankments and subgrade courses for pavement structures, while production of sub-base and base courses is not recommended because of non-compliance with the relevant standard;

- Fly ash should be incorporated in the body of the road in segments, where it will be isolated from the effects of frost, surface water, and groundwater. This would prevent washout of chemical pollutants from the ashes in operating conditions, and their penetration into the water environment.

- The relation between physico-mechanical properties shows good correspondence for all fly ash samples from PPNT A and PPNT B. However, samples taken from PPNT A show better correlation coefficients compared to the samples taken from PPNT B;

It can generally be concluded based on this research that fly ash can be used as a substitute for natural materials in construction industry, which will contribute to preservation of limited natural resources, and hence to sustainable development. 


\section{REFERENCES}

[1] Miletić, S., llić, M.: Korišćenje elektrofilterskog pepela u građenju i građevnim materijalima, Prvo izdanje, Savez građevnih inženjera i tehničara Srbije, 2007.

[2] Kouloumbi, N., Batis, G.: Chloride corrosion of steel rebars in mortars with fly ash admixture, Cement and Concrete Composites, 14 (1992) 3, pp. 199-207.

[3] Kouloumbi, N., Batis, G.: The anticorrosive effect of fly ash, slag and a Greek pozzolan in reinforced concrete, Cement and Concrete Composites, 16 (1994) 4, pp. 253-260.

[4] An, J., Kim, J., Golestani, B., Tasneem, K., Al Muhit, B., Huyan Nam, B., Behzadan, A.: Evaluating the Use of Waste-to-Energy Bottom Ash as Road Construction Materials, Draft Final Report, University of Central Florida, 2014

[5] Skazlić, M., Rosković, R., Banjad Pečur, l.: Svojstva samozbijajućeg betona s velikim udjelom letećeg pepela, GRAĐEVINAR, 60 (2008) 11, pp. 945-952.

[6] Chousidis, N., Rakanta, E., loannou, I., Batis, G.: Mechanical properties and durability performance of reinforced concrete containing fly ash, Construction and Building Materials, 101 (2015), pp. 810-817, https://doi.org/10.1016/j.conbuildmat.2015.10.127

[7] Soriano, L., Paya, J., Monzo, J., Borrachero, M.V., Tashima, M.M.: High strength mortars using ordinary Portland cement-fly ashfluid catalytic cracking catalyst residue ternary system (OPC/FA/ FCC), Construction and Building Materials, 106 (2016), pp. 228235, https://doi.org/10.1016/j.conbuildmat.2015.12.111

[8] Dragaš, J., Marinković, S., Ignjatović, I., Tošić, N.: Properties of highvolume fly ash concrete and its role in sustainable development, $40^{\text {th }}$ International conference Contemporary achievements in civil engineering, Subotica, pp. 849-858.

[9] Monhanty, S., Patra, N.,R.: Dynamic response analysis of Talcher pond ash embankment in India, SOIL Dynamics and Earthquake Engineering, 84 (2016), pp. 238-250, https://doi.org/10.1016/j. soildyn.2016.01.021

[10] Sankaran, K.S., Rao, D.R.: The influence of the quality of filter in asphaltic paving mixtures, Indian Roads Congress, 1973.

[11] Henning, N.E.: Evaluation of lignite fly ash as a mineral filler in asphaltic concrete, Report No. Item 2 (73), Twin City Testing and Engineering Laboratory, St. Paul, Minnesota, 1974.

[12] Tapkin, S.: Improved asphalt aggregate mix properties by portland cement modification, Transport Research Board, pp. 606-614, 2000., http://worldcat.org/isbn/9080288438

[13] Suheibani, A.R.S.: The use of fly ash as an asphalt extender, PhD Dissertation, University of Michigan, Ann Arbor, 1986.

[14] Cabrera, J.G., Zoorob, S.: Design of low energy hot rolled asphalt, The Civil Engineering Materials Unit, Department of Civil, University of Leeds, 1994.

[15] Baykal, G., Edincliler, A., Saygili, A.: Highway embankment construction using fly ash in cold regions, Resources, Conservation And Recycling, 42 (2004), pp. 209-222, https://doi.org/10.1016/j. resconrec. 2004.04 .002
[16] Vestin, J., Arm, M., Nordmark, D., Lagerkvist, A., Hallgern, P., Lind, B.: Fly ash as a road construction material, Conference on WASCON 2012, Linkoping, pp. 1-8.

[17] Vukićević, M., Pujević, V., Marjanović, M., Jocković, S., MarašDragojević, S.: Stabilizacija sitnozrnatog tla letećim pepelom, GRAĐEVINAR， 67 (2015) 8, pp. 761-770, https://doi. org/10.14256/JCE.1281.2014

[18] Tadić, G., Gligorić, M., Došić, A., Grujić, R.: Upotreba elektrofilterskog pepela u izgradnji saobraćajnica, Journal of Engineering \& Processing Management, 7 (2015) 1, pp. 125-139.

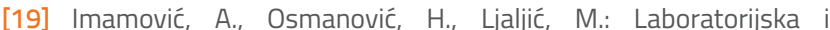
eksperimentalna istraživanja primjene elektrofilterskog pepela i šljake u izgradnji saobraćajnica, Savjetovanje o primjeni elektrofilterskog pepela i šljake u izgradnji putne infrastrukture, Tuzla, pp. 20-29, 2003.

[20] Pavlović, V., Matko, Z.: Rekultivacija degradiranog prostora reik Kolubara, Geološka istraživanja u privrednom i prostornom razvoju Beograda, Beograd, pp. 564-584, 1984

[21] EN 14227-4: Hydraulically bound mixtures - Specifications - Part 4: Fly ash for hydraulically bound mixtures, 2001.

[22] ASTM C-618: Standard specification for coal fly ash and raw or calcinde natural pozzolan for use as material admixture in concrete, American society for testing and materials, West Cons hohocken, PA, USE, ASTM International, 2003.

[23] EN 13286-41: Unbound and hydraulically bound mixtures Part 41: Test method for the determination of the compressive strength of hydraulically bound mixtures, 2003.

[24] EN 13286-43: Unbound and hydraulically bound mixture - Part 43: Test method for the determination of the modulus of elasticity of hydraulically bound mixtures, 2002

[25] SRPS U.B9.012: Procena osetljivosti kolovozne konstrukcije na dejstvo mraza i tehničke mere za sprečavanje oštećenja, Institut za standardizaciju Srbije, Beograd, 1981.

[26] SRPS U.B1.50: Geomehanička ispitivanja: Ispitivanje otpornosti cementom stabilizovanog tla prema mrazu, Institut za standardizaciju Srbije, Beograd, 1970.

[27] EN 13286-42: Unbound and hydraulically bound mixtures - Part 42: Test method for the determination of the indirect tensile strength of hydraulically bound mixtures, 2003.

[28] SRPS U.E9.024: Izrada nosećih slojeva kolovoznih konstrukcija puteva od materijala stabilizovanih cementom i sličnim hidrauličnim vezivima, Institut za standardizaciju Srbije, Beograd, 1980

[29] SRPS U.E9.026: Izrada stabilizovanog tla krečom i izrada nosećih slojeva za puteve od materijala stabilizovanih krečom, Institut za standardizaciju Srbije, Beograd, 1982. 